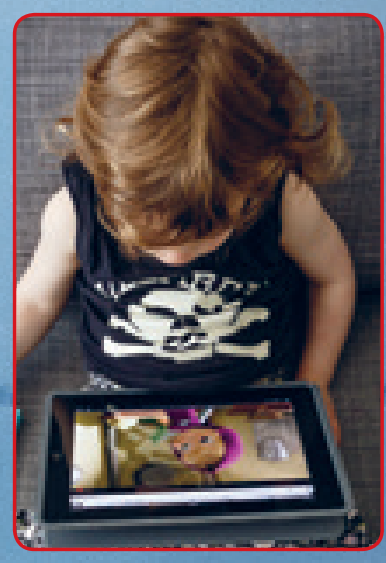

\title{
SEKTORPROGRAM
}

\section{Social- og sundhedspolitik}

\section{Dansk formandskab for}

Nordisk Ministerråd 2015

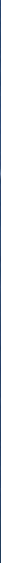


Sektorprogram for social- og sundhedspolitik

Danmarks formandsskab i Nordisk Ministerråd 2015

ISBN 978-92-893-3924-7 (PRINT)

ISBN 978-92-893-3925-4 (PDF)

http://dx.doi.org/10.6027/ANP2015-704

ANP 2015:704

(C) Nordisk Ministerråd 2015

Lillegrund Vindmøllepark Øresund, Danmark/Sverige

Layout: Erling Lynder

Omslagsfoto: Havvindmøller i Øresund,

Adrian Joachim og Yadid Levy

Foto: s. 6 Magnus Fröderberg, s. 7, 9 og 10 Yadid Levy

www.norden.org/da/publikationer

\section{Det nordiske samarbejde}

Det nordiske samarbejde er en af verdens mest omfattende regionale samarbejdsformer. Samarbejdet omfatter Danmark,

Finland, Island, Norge og Sverige samt Færøerne, Grønland og

Åland.

Det nordiske samarbejde er både politisk, økonomisk og kulturelt forankret, og er en vigtig medspiller i det europæiske og internationale samarbejde. Det nordiske fællesskab arbejder for et stærkt Norden i et stærkt Europa.

Det nordiske samarbejde ønsker at styrke nordiske og regionale interesser og værdier i en global omverden. Fælles værdier landene imellem er med til at styrke Nordens position som en af verdens mest innovative og konkurrencedygtige regioner.

\section{Nordisk Ministerråd}

Ved Stranden 18

1061 København $\mathrm{K}$

Telefon (+45) 33960200

www.norden.org 


\section{norden}

SEKTORPROGRAM

Social- og sundhedspolitik

Dansk formandskab for Nordisk Ministerråd 2015

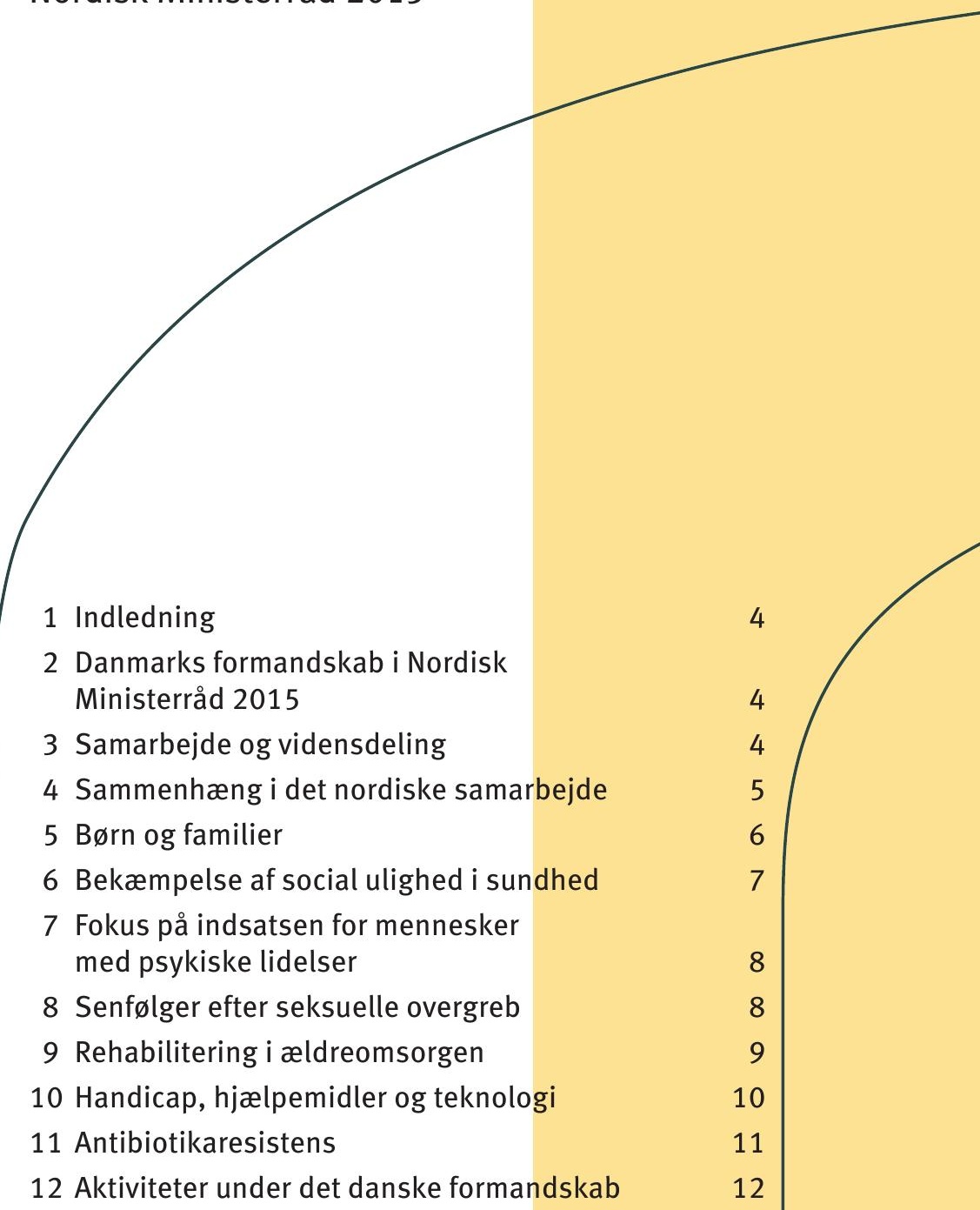




\section{Indledning}

\section{Danmarks formandskab i Nordisk Ministerråd 2015}

"Sammen er vi stærke". Det var de nordiske samarbejdsministres vision for det nordiske samarbejde fra 2014 - og det vil også være ledetråd for det danske formandskab i 2015.

Det danske formandskab vil stille skarpt på vækst, værdier og velfærd med målet at styrke og fokusere det nordiske samarbejde til gavn for borgere, samfund og virksomheder.

Norden er kendt over hele verden for sin velfærdsmodel. De nordiske lande har alle ambitiøse offentlige strategier på velfærdsområdet og stærke velfærdssystemer, der grundlæggende minder om hinanden.

Vi har derfor i Norden i langt højere grad end i andre dele af verden et stærkt fundament for at kunne samarbejde og udnytte fælles offentlige og private ressourcer på velfærdsområdet til gavn for borgerne.

\section{Samarbejde og vidensdeling}

Øget samarbejde og vidensdeling er også en nødvendighed, da de enkelte lande i Norden ofte er for små til at have tilstrækkelig med forskning og relevant viden om gode løsninger, metoder og indsatser.

Formandskabet vil derfor arbejde for at etablere et stærkere samarbejde inden for udvalgte velfærdsområder og samtidig sikre, at Nordens fælles ressourcer og potentiale udnyttes for herigennem at skabe konkret merværdi for de nordiske borgere.

Bo Könberg-rapporten om det fremtidige samarbejde på social- og sundhedsområdet er et fint eksempel herpå.

Endvidere er der et stadigt behov for at afvikle og forhindre grænsehindringer, så borgere og virksomheder i højere grad kan udnytte potentialet i at høre hjemme i Norden.

Gennem det nordiske samarbejde har vi en unik mulighed for at skabe øget velfærd for borgerne i de nordiske lande. 


\section{Sammenhæng i det nordiske samarbejde}

Det er vigtigt, at der ses en kontinuitet i det nordiske samarbejde. At der ses en samhørighed i de projekter, der igangsættes, og at nye projekter bygger på erfaringerne fra tidligere projekter. Alt sammen så vi kan samle erfaringerne og arbejde videre på grundlag af mere og bedre nordisk viden.

Det danske formandskab vil derfor bygge videre på stenene fra de tidligere formandskaber, som er beskrevet i Strategien for Socialog Sundhedssamarbejde, og på initiativerne i programmet Holdbar Nordisk Velfærd. 


\section{Børn og familier}

Danmark vil under overskriften kontinuitet $i$ anbringelse af børn og unge i plejefamilie følge op på de initiativer som Sverige og Island igangsatte under deres formandskaber på området for børn og familier. Familiepleje er den hyppigst anvendte anbringelsesform i Norden, og i Danmark er over halvdelen af de børn og unge, der er anbragt uden for hjemmet, placeret i familiepleje.

Det er fælles viden i de nordiske lande, at en stor del af de børn og unge, som er anbragt på grund af socialt betingede forhold, gennemgående klarer sig dårligere, end deres jævnaldrende på parametre som: grundskole, ungdomsuddannelse, psykisk og fysisk helbred, kriminalitet, misbrug samt videregående uddannelse, beskæftigelse og selvforsørgelse.

Kontinuitet i anbringelse af børn og unge i plejefamilie er en af de faktorer, der giver børn og unge ro til at bevæge sig i en positiv retning. For at sikre bedre forudsætninger for stabilitet $i$ anbringelsen og dermed bedre forudsætninger for vellykkekede anbringelsesforløb, er det vigtigt at have fokus på blandt andet plejefamiliernes arbejdsforhold og kompetencer.

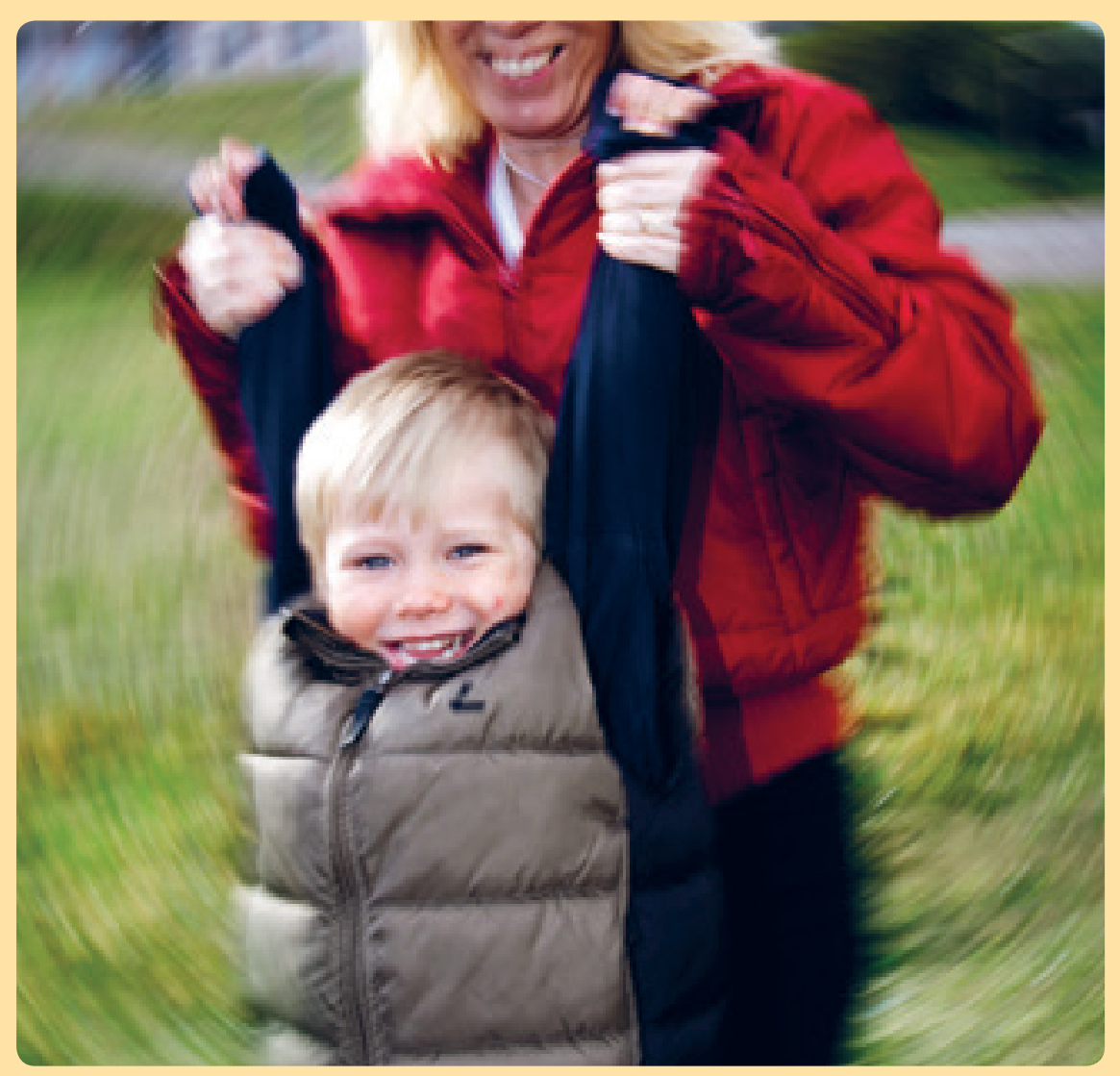




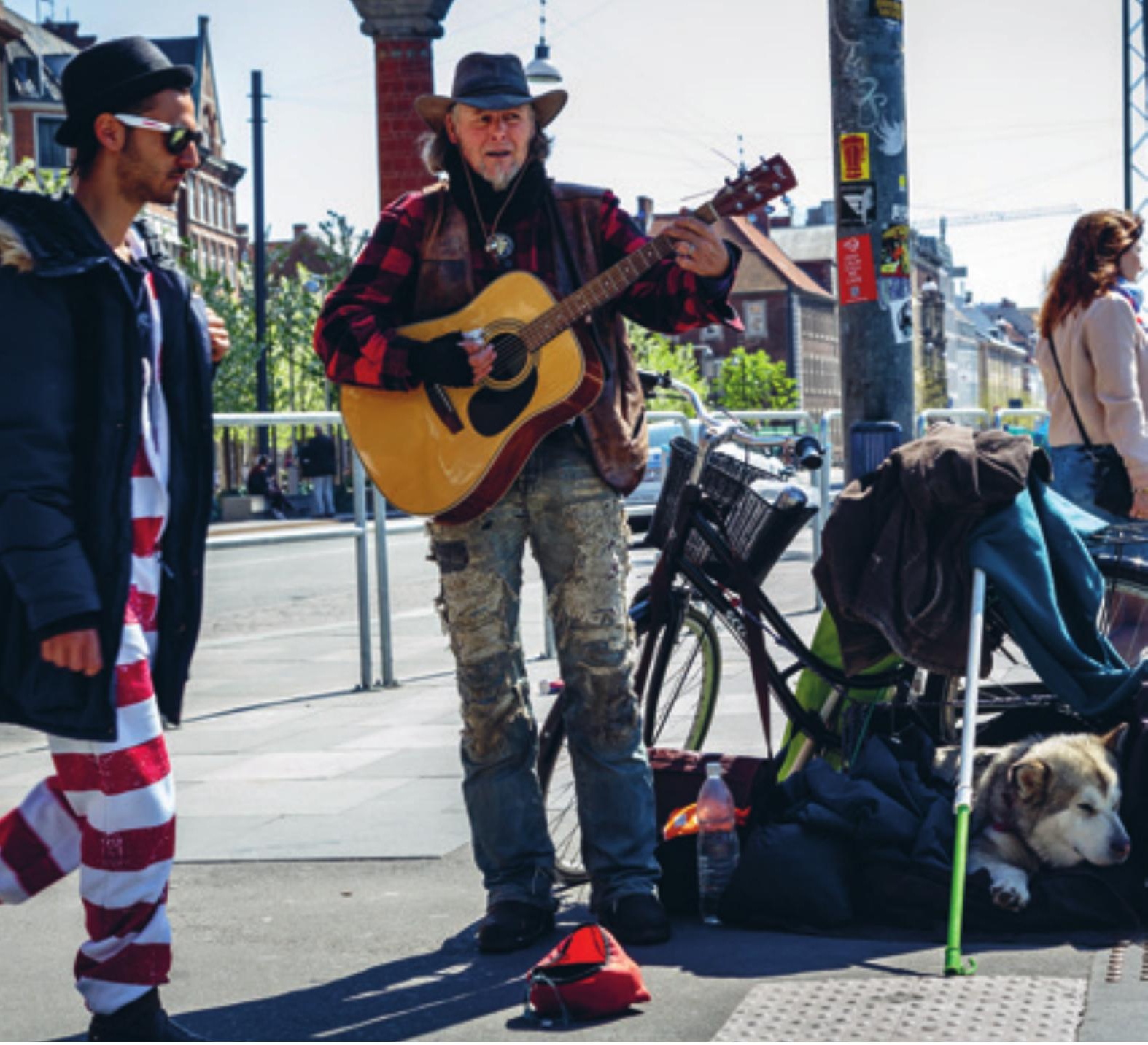

\section{Bekæmpelse af social ulighed i sundhed}

Alle nordiske lande oplever, at sundhed og et godt helbred er ulige fordelt i befolkningen. Uligheden i sundhed grundlægges allerede fra fødslen og viser sig eksempelvis ved, at færre børn af forældre med en kort uddannelse kommer til børneundersøgelser og bliver vaccineret. Andre faktorer så som rygning, alkohol samt kost og motion har også betydning for ulighed $i$ sundhed.

En række sociale faktorer som tidlig opsporende indsatser af mistrivsel, fastholdelse i uddannelse for unge, og tilknytning til arbejdsmarkedet er væsentlige prædiktorer for dårligt helbred og social ulighed i sundhed. Effektive indsatser til at reducere den sociale ulighed i sundhed er identificeret i en række nationale undersøgelser.

Der er ved at blive udarbejdet en undersøgelse som har fokus på hvordan indsatser mod social ulighed i sundhed kan implementeres. Undersøgelsen involverer en række af de nordiske lande. Det danske formandskab vil bygge videre på erfaringerne fra dette studie. 


\section{Fokus på indsatsen for mennesker med psykiske lidelser}

Det islandske formandskab satte i 2014 fokus på psykisk helse med både en konference og et ekspertmøde. Det danske formandskab bygger videre herpå, da psykiske lidelser berører mange mennesker hver eneste dag og kan have alvorlige konsekvenser for såvel den enkelte som for dennes pårørende. Ligesom med somatiske sygdomme er det muligt at komme sig helt eller delvist efter en psykisk lidelse, også i forhold til psykiske vanskeligheder af alvorlig karakter.

Danmark ønsker at følge op på Bo Könberg rapportens anbefaling om et topmøde om psykisk sundhed og afholde det første topmøde.

\section{Senfølger efter seksuelle overgreb}

Senfølger efter seksuelle overgreb i barndommen er kendetegnet ved en lang række psykiske og sociale problematikker i voksenlivet, hvoraf nogle diagnoser synes at optræde oftere end andre.

Blandt de hyppigst forekommende senfølger efter seksuelle overgreb kan nævnes PTSD, angst og depression. Øvrige senfølgeproblematikker kan være lavt selvværd, tvangsforestillinger, problemer med krop og seksualitet, selvskadende, suicidal og seksualiseret adfærd, spiseforstyrrelser og stofmisbrug.

Viden om senfølger efter seksuelle overgreb er begrænset, og afholdelsen af en konference vil udgøre et væsentligt bidrag til at udveksle viden og erfaringer inden for Norden. Fokus for konferencens indhold vil være organiseringen af indsatserne i de nordiske lande og de hertil knyttede udfordringer og muligheder. Konferencen kan desuden bidrage til at bryde med tabuer, der omgiver senfølger efter seksuelle overgreb. 


\section{Antibiotikaresistens}

Udvikling af antibiotikaresistens hos mennesker og dyr er et stadigt større problem i de nordiske lande og globalt, og samtidig opstår der i stigende omfang problemer med bakterier, der er resistente over for flere typer af antibiotika - de såkaldte multiresistente bakterier. Det anslås, at der årligt dør omkring 25.000 mennesker i EU på grund af infektioner med resistente bakterier.

Danmark vil følge op på Könberg-rapporten, som blandt andet udpeger antibiotikaresistens som et område med potentiale for styrket nordisk samarbejde. Danmark vil herudover støtte op om samarbejdet vedr. bekæmpelse af antibiotikaresistens i et One Health-perspektiv, som er blevet etableret $i$ regi af en ny nordisk arbejdsgruppe om antibiotikaresistens. 


\title{
Aktiviteter under det danske formandskab
}

På www.sum.dk og www.sm.dk kan løbende følges information om aktiviteter under formandskabet.

Møder i ministerrådet for social- og sundhedspolitik (MR-S) og embedsmandskomitéen for social- og sundhedspolitik (EK-S) 2015

\author{
25. - 26. februar EK-S (1) \\ Sted: Torshavn, Færøerne
}

27. - 28. maj EK-S (2)

Sted: Ilulissat, Grønland.

9. september MR-S

Sted: København, Sekretariatet

3. - 4. november EK-S (3)

Sted: København, Sekretariatet. 


\title{
Møder, seminarer og konferencer
}

\author{
WS 1-24. marts Workshops om anbragte børn og unge \\ WS 2 - 19. maj Sted: København \\ Nordiske forskere og embedsmænd vil i 2 workshops \\ bidrage til at udveksle erfaringer og viden, der kan \\ danne basis for et vidensgrundlag med anbefalinger. \\ Workshop 1 vil være dialog om forskelle og ligheder \\ samt fælles udfordringer. Workshop 2 vil have fokus \\ på løsningsmodeller og anbefalinger.
}

\section{8. - 19. marts Netværksmøde med temaet rehabilitering}

Sted: København

På mødet kan relevante aktører i departement og direktorater/styrelser i det enkelte land få let adgang til konkret viden og inspiration, der kan indgå i de nationale overvejelser om nye initiativer på feltet. Formandskabet for netværket følger formandskabet for nordisk ministerråd.

13. - 14. april Inspirationsseminar om individtilsyn (autorisation)

I regi af den nordiske gruppe for sundhedspersonale afholdes et inspirationsseminar om individtilsyn.

\section{9. - 30. maj Seminar om senfølger efter seksuelle overgreb}

Sted: Ilulissat, Grønland

Det er hensigten, at seminaret skal munde ud i etableringen af et nordisk netværk på området for senfølger efter seksuelle overgreb, hvor der bl.a. vil være mulighed for at dele gode erfaringer og viden om metoder og effekter i arbejdet med senfølger efter seksuelle overgreb. 
Afholdelse af ekspertmøde med henblik på drøftelse af den videre proces for et styrket samarbejde mellem de nordiske lande om bekæmpelse af antibiotikaresistens - herunder drøftelse af eventuelle fælles nordiske projekter.

\begin{tabular}{ll}
\hline August & $\begin{array}{l}\text { Psykiatri topmøde } \\
\text { Sted: København }\end{array}$ \\
& Könberg-rapporten beskriver et årligt topmøde \\
& inden for psykisk sundhed. Det danske formandskab \\
& vil afholde det første topmøde.
\end{tabular}


28.-29. oktober Workshop om brug af hjælpemidler og teknologi Sted: København

Formålet med workshoppen er at udveksle erfaringer og viden, der kan danne basis for en mindre ideopsamling baseret på aktuelt bedste viden og praksiserfaringer fra de enkelte lande. Hver deltager skal bidrage med oplæg og tekststykke til ideopsamlingen, som samles af Socialstyrelsen.

\section{December 2015 Konference om social ulighed i sundhed}

Afholdelse af konference om social ulighed i sundhed 


\section{norden}

Nordisk Ministerråd

Ved Stranden 18

DK-1061 København K

www.norden.org

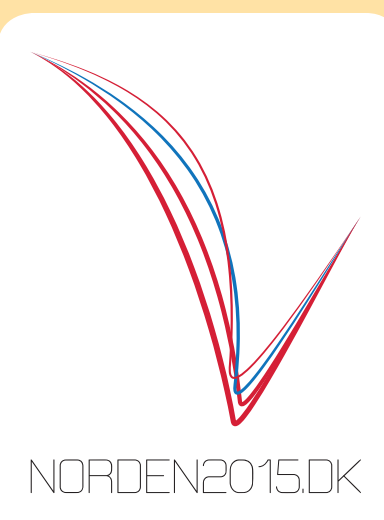

Yderligere information om Danmarks formandskab fås på www.norden2015.dk

Udenrigsministeriet Sekretariatet for Ministeren for Nordisk Samarbejde norden2015@um.dk

Asiatisk Plads 2

DK-1448 København K Danmark

Telefon: +45 33920000

ANP 2015:704

ISBN 978-92-893-3924-7 (PRINT)

ISBN 978-92-893-3925-4 (PDF)

http://dx.doi.org/10.6027/ANP2015-704 